\title{
LAND, SPACE, AND PEOPLE: CONSTRAINTS OF THE CAPITALIST WORLD-ECONOMY ${ }^{1}$
}

\author{
Immanuel Wallerstein \\ Department of Sociology \\ Yale University \\ immanuel.wallerstein@yale.edu
}

\begin{abstract}
The coming into existence of the capitalist world-economy created new constraints on utilizing the land for productive purposes. The single most important change is that it established a systematic legal basis for what is called title to the land. Title to the land is fundamentally a political question masked by a legal veneer. The amount of land that is governed by title is, even today, not 100\% of the global land surface. But it has grown as a percentage of the total global land surface throughout the history of the modern world-system. Population growth has led to two forms of expansion. There is extensive growth, the bringing of more and more land areas into the system of titled land. But there is also intensive growth, the ever greater concentration of the population of the world into close-contact areas. We call this urbanization. The world left faces a fundamental dilemma. On the one hand, the world left has stood for measures that would reduce the enormous real north-south gap. On the other hand, the world left (or at least a growing portion of it) is standing against further commodification of land rights and further ecological degradation of the world. The two strategies are contradictory and incompatible one with the other. Land rights stand as the crucial deciding point.
\end{abstract}

\section{INTRODUCTION}

The land was there before the existence of a capitalist world-economy. And people lived on the land and off the land. The relationship different peoples had to the land they used in one way or another varied considerably. There were different customary rules about rights to utilize the land. The crucial point was that these rules very seldom existed in written form.

Some peoples were essentially nomadic, which meant they physically moved over time from place to place, although the range of places may have been constrained by customary agreements. Other peoples engaged in settled agriculture, which usually implied some right to land usage, and some possibility of inheritance of these rights. In many situations, there were persons who did not use the land themselves for production but claimed the right to receive

\footnotetext{
${ }^{1}$ Keynote address at $34^{\text {th }}$ Political Economy of the World-System conference, "Land Rights in the World-System," Florida Atlantic University, April 22, 2010.
}

Copyright @2012, American Sociological Association, Volume XVIII, Number 1, Pages 6-14 ISSN 1076-156X 


\section{JOURNAL OF WORLD-SYSTEMS RESEARCH}

transfers of the usufruct in one form or another from the direct users. Generically, we may call them overlords, who often repaid these transfers by offering some kind of protection to the direct producers. It was seldom the case that individuals, either direct users or overlords, had the kind of title to the land that legitimated the sale of their rights to others. The coming into existence of the capitalist world-economy changed all this in fundamental ways, creating new constraints on utilizing the land for productive purposes. It is these constraints that I wish to explore in this paper, which raises more questions than it offers a series of analytic propositions about land rights in the world-system.

\section{TITLE TO THE LAND}

The single most important change imposed by the modern world-system is that it established a systematic legal basis for what is called title to the land. That is to say, rules were created by which an individual or a corporate entity could "own" land outright. Owning land -that is, property rights- meant that one could use the land in any way one wanted, subject only to specific limitations established by the laws of the sovereign state within which this unit of land was located. Land to which one had title was land that one could bequeath to heirs or sell to other persons or corporate entities.

How did one acquire title to land that previously had no title in this specific legal sense? The answer by and large was that one seized such land and simply proclaimed oneself owner of the land. Sometimes this occurred by legal authorization from a superoverlord (like a king). And sometimes it occurred in situations of conquest of a region by a state, which then authorized such seizures. Usually the conquering state initially authorized such seizures to participants in the conquest. And then later, this authorization might have been extended to anyone the conquering state in question wished to permit to seize the land.

Generally, this was considered "development" of the land, or in that wonderful French expression, mise en valeur. Let us dwell for a moment on the French expression - in wide use until at least 1945. Literally, the word valeur means "value." So if one put something (mise) into value, one means that it then acquired value within a capitalist economic system. Presumably, before the mise en valeur, it did not have such value; and afterwards, it did.

Of course, in almost every case, this land previously had been "used" for some purpose by someone. However, once title was granted to a seizer, the person or group that previously "used" the land lost whatever customary rights they had had, or thought they had had, to the land. Quite often, they were literally evicted from the land. Or else, they were allowed to remain on the land in some subordinate capacity, as defined by the person who now held title to the land.

Such seizure of previously untitled land has been going on for the past five centuries. It is still going on today in whatever units of land still remain somehow outside the domain of land to which there is legal title.

Seized land may, under certain political conditions, be reseized by persons who do not have legal title. This is largely done by what we call "squatting" on the land. There are today organized social movements which proclaim the moral and political right to squat, particularly if the land in question is not being used actively, or if the person who has title is a distant landlord. 


\section{JOURNAL OF WORLD-SYSTEMS RESEARCH}

In many cases, the squatters are actual cultivators of the land who, however, do not have legal title. For example, the Movimento dos Trabalhadores Sem Terra (MST) is a powerful social movement in Brazil that specifically works to permit reseizure of the land. They seek further, so far without much success, to get the Brazilian government to legitimate such reseizure. Squatting also occurs in urban zones in unoccupied buildings.

Of course, the government itself can reseize land, by a legal process called eminent domain. This has often occurred in various parts of the world. Normally to invoke eminent domain the government must proclaim some social interest of the state in preempting usage of the land. They may seize the land of small landowners in order to give it to larger landowners, in order that the latter "develop" it in some way that is deemed more productive. But the government may also do it as a political gesture, to take land from persons considered outside/foreign settlers and "restore" it to persons considered somehow indigenous to the state.

Both government seizure for "development" and squatting can, and do, occur not only in rural areas, where the land is used for some agrarian purpose, but in urban areas where the land is used first of all for housing. Government seizures on behalf of corporate housing developers occur with some frequency. But seizure by squatting is also commonplace. These days, large urban areas, particularly in the global South, have extensive zones of settlement (such as bidonvilles, favelas, etc.) in which there is such squatting - sometimes tolerated de facto by the legal authorities, sometimes repressed, provided the state has sufficient means to suppress it.

The basic point is that title to the land is fundamentally a political question masked by a legal veneer. Title to the land may or may not be enforced by legal authorities, who are thereby making a political decision. In this regard, Proudhon's famous slogan "property is theft" is no doubt the most apt description of land title.

The main ongoing legal and political issue is what happens after the initial seizure. If a piece of property is acquired by theft, and is passed down to descendants for multiple generations thereafter, or sold to others, does de facto continuity of legal ownership confer either moral or legal rights to the land? This is the issue raised today by movements of so-called Indigenous peoples that are laying claim either to recovery of land (full ownership) or at least to financial compensation for land that had been seized-in many cases, centuries earlier.

Virtually the entire land area of so-called lands of settlement was originally seized in this manner. This applies notably to areas of overseas European settlement-North America, Australasia, the southern cone of Latin America, southern Africa, and Israel. It applies, however, as well to the areas of purely land-based European expansion, as Russia into Siberia and the Caucasus. Actually, of course, the same process is to be found in the expansion in those areas wherein stronger non-European groups move into adjoining areas that are weaker politically. This is what has happened historically in China, in India, and in the many parts of Africa that were not White settler areas.

The main point is that the process of legitimating ownership by legal title is a fundamental process of the capitalist world-economy. And its origin almost always lay in seizure by force. But since it has been a virtually universal practice, undoing this process is akin to leveling the Himalayas or the Alps. I suppose it might be technically possible, but it is politically impossible. This does not mean that adjustments cannot be made as a result of pressure by social 


\section{JOURNAL OF WORLD-SYSTEMS RESEARCH}

movements. But any adjustments would necessarily constitute unsatisfactory compromises of mutually incompatible assertions of moral and legal rights.

Why do people seize land? The obvious primary answer is that it is economically profitable in some way to do so. It may be profitable because the land offers good possibilities for production for the market. But it may also be indirectly profitable because it pushes some people off the land, and such persons may then have to seek remunerative employment elsewhere and thereby serve the need of capitalist producers elsewhere.

Of course, some of the land seized may not in itself offer much opportunity for profitable production. It may be seized for "strategic" reasons - to defend the collectivity of owners from counterpressures or countermovements, to guarantee the possibilities for long-range transportation of merchandise, or simply to deny the use of the land to other states or their citizens.

\section{SPACE}

The amount of land that is governed by title is, even today, not $100 \%$ of the global land surface. But it has grown as a percentage of the total global land surface throughout the history of the modern world-system. Some people have always fought back, resisting the demand to create title on the land they have customarily used. And some people have escaped the consequences of their land having been seized by fleeing to other land areas that are more remote from the persons engaged in doing the seizing. This is what James Scott has called "the art of not being governed." It accounts for the emergence and creation of zones in, for example, high mountainous areas, which are considered both "traditional" and "primitive" by the holders of titled land rights. These same zones, however, are considered zones of libertarian resistance by those who have thus escaped. These zones are as doubtfully "traditional" (that is, pre-modern) as most other phenomena we like to brand negatively as traditional.

The basic pressure on those who have sought to escape the process of the assertion of restrictive land rights has been population growth. We know that the population of the world has been growing steadily for the past 500 years. With only marginal exceptions- the results of landfills-the area of the globe on which people can live has remained the same. So, there are continuously more people per square mile globally.

Population growth has led to two forms of expansion. There is extensive growth, the bringing of more and more land areas into the system of titled land. But there is also intensive growth, the ever greater concentration of the population of the world into close-contact areas. We call this urbanization. This is a process no one doubts and which, in the last fifty years, has accelerated at a breathtaking rate, such that we have moved into a world of multiple megalopolises, with the prospect of still more and still larger ones in the decades to come.

The two processes together - extensive and intensive occupation of land areas governed by the legal processes of the world-system - have created a whole range of additional constraints on the ways in which the capitalist world-economy operates. It seems elementary to observe that the situation of more people on the same amount of land creates a pressure on every conceivable kind of resource that humans need to survive. It also seems elementary to observe that if humans 


\section{JOURNAL OF WORLD-SYSTEMS RESEARCH}

appropriate more land, they inevitably have to eliminate competing users of the land- mostly fauna but also flora.

While these processes have been in operation throughout the history of the capitalist world-economy, they have become a cultural and political issue particularly in the last fifty years, as the ecological effects of the modern world-system have become more and more obvious and the negative aspects more and more blatant.

The first problem is water. Water is essential to life processes. The amount of usable water in the world is not unlimited. One of the controversial features of land title is the degree to which it involves total control of water resources that are accessible on the titled land in question. The water conflicts between settled farmers and ranchers are so central to the modern world that much modern fiction is devoted to discussing it. The conflict between rural users and urban consumers is equally notorious.

What happens as a consequence? Governments make decisions about allocations, which they then implement by various alterations of the land surface in order to ensure certain kinds of flows of water that give preferential access to water to particular groups. The construction of dams is one tried and true technique of doing this. When dams change the flow of water and access to the water, they of course affect most immediately the land rights of owners and users in or near the trajectory of the rivers that are being dammed.

There is, however, an additional, more long-term effect. The process of altering flows and access leads over time to more extensive usage of the available water and eventually to desertification. This thereby reduces the available water supply at the very same time as the numbers of persons seeking water worldwide has increased.

Furthermore, this is more than a question of the use of water that is located in rivers and lakes and in the water table underneath the land areas. The demand for food resources leads to more and more intensive usage of the ocean areas as sources of food supply. Title to ocean areas has been increasingly asserted by states. The historic claim that a three-mile zone at the edge of land frontiers falls under a state's sovereignty has escalated in recent decades into claims for a 200-mile zone. And tomorrow still wider zones will almost surely be claimed.

The commodification of water - by individuals, by enterprises, and by states - has expanded enormously, as the reality of worldwide water shortages has become more evident. Of course, commodification of a vital resource means that there results increasingly unequal allocation of the resource. Water struggles have thus become a central focus worldwide of the class struggle.

What is true of water is equally true of food and energy resources. If there are more people in the world, it means that more total food resources are needed. Since land is increasingly appropriated for human use, there is less room for animals that roam. The world has turned therefore to farming animal resources- that is, concentrating their location in small, enclosed areas, controlled by ever larger corporate enterprises. This not only polarizes distribution but has important negative health consequences both for the humans and the animals.

The interstate conflicts over access to energy have become the everyday story of the media. What is also much discussed these days is the ecological dangers resulting from the kinds of energy utilized, and its impact on world climatic conditions. This is in turn leading to one of 


\section{JOURNAL OF WORLD-SYSTEMS RESEARCH}

the last, but not least, commodifications, that of the air we breathe. Title to land meant initially title to what was on the land surface. But quite quickly, it was extended to mean what lies beneath the land surface, and more recently to what is in the oceans. Now it has begun to be asserted to the air rights above the land surface.

As more and more goods are produced on less and less land area per person in the world, the issue of the disposal of toxic waste has loomed heavily. Who has title to toxic waste, and where can it be deposited in a system in which there is title to land? We know what is happening. As the dangers of toxic waste to human survival have become more well-known, it has become less and less legitimate to dispose of it in the public domain. This is not to say that such disposal has ceased- far from it-but it has become less legitimate and therefore the disposers act more secretively.

The alternative to disposal in the public domain is disposal by purchased access to land (or water) zones to which others have title. Where this can be done is of course in direct correlation with the relative strength of zones within the world-system. In wealthier zones, political resistance to purchased waste disposal sites is strong and relatively effective. This is the so-called NIMBY phenomenon. The purchase of rights tends therefore to mean increasingly purchases in the global South, which further increases the polarization of the world-system.

Once again, this affects the land rights of those closest to the disposal areas. But it also affects the long-term class struggle- in this case not over access but over non-access.

The basic issue can be readily summed up. More people equals more resource needs. To the extent that resources are allocated within a system of title to land rights, the result is fewer resources per person, more commodification, more ecological damage, and more acute class struggle worldwide.

\section{PEOPLE AND PEOPLES}

After 500 years of the operation of a capitalist world-economy, where are we today, in terms of both people and peoples? That is, what has been the impact on the lives of individuals? And what has been the impact on the lives of groups? And perhaps most importantly, what can either individuals or groups do about this impact? And what are they doing about it?

If we start with people as individuals or quite small groups like families, it is quite clear that their options and their freedom of action is constrained in very important ways as the result of creating a system in which the use of land is governed by so-called title, that is, by property relations.

It is reasonably important to look carefully at the concept of freedom of action. At a superficial level, acquiring title to land seems to enhance individual rights. The owner can dispose of this property as the owner wishes, subject to a small number of legal limitations. The owner, it is argued, benefits directly from the owner's work input, in that the owner can retain the benefits of improving the property.

This is no doubt more or less accurate. However, it leaves out of the equation the unequal strength of different property-owners, and therefore of the ability of larger, stronger owners to 


\section{JOURNAL OF WORLD-SYSTEMS RESEARCH}

outcompete smaller ones and in effect force a transfer of ownership. This is what we call concentration of capital.

An obvious simple example can illustrate this. Take two instances of where collective property without individual rights to title existed and then was transformed into individual rights to a small portion of the collective property. One would be a rural zone in the global South previously outside the system of titled land rights. A second would be collective property in the ex-Communist states in the period following 1989. In both cases, mandated privatization of the property created multiple small owners who, however, were unable to maintain the property in a market situation. They thereupon sold their rights to some larger entrepreneur. At the end of this process, they had lost all rights within the erstwhile collective property, and economically were likely to be worse off than before.

As we have seen, this is only a small part of the story. If we look at the demographic and ecological consequences of the system over 500 years, we observe a considerable and growing polarization of the world-system which, at an individual level, has translated into a vast growing population who live below what is considered the "poverty level." This is often masked by the considerably improved situation for perhaps $15-20 \%$ of the world's population.

What has happened to individual people is perhaps less dramatic than what has happened to peoples. Groups of people - peoples - all like to assert their eternal existence and their eternal moral right to exist and persist. This is of course mythology. Groups come into and out of existence all the time, and always have.

Is there something different about this process within the framework of the modern world-system? Well, yes and no. The answer is no if one emphasizes the fact that groups have lives, that they are constantly changing in structure and design, in values and boundaries, in size and importance.

But the answer is yes if we look at how groups come into and out of existence in the modern world-system, as contrasted with how they did so previously. It has very much to do with land rights. The modern world-system has made possible, via technological improvements, larger and more rapid movements of peoples. We lump all these movements under the vague cover label of migration. But this greater technological facility of movement has occurred at the same time that there has been created an historical system that is composed of so-called sovereign states within an interstate system. These states have boundaries (albeit changing ones). And by systemic definition, there are no zones outside this carving up of the world into sovereign states (except marginally, and perhaps not for very much longer, the once totallyunoccupied Antarctic).

Sovereign states, as part of their mechanism of survival as institutions, have by and large all sought to become so-called nation-states. That is, they have all (or almost all) practiced an underlying Jacobin ideology of integration. They have wanted to insist that the multiple peoples located within their borders become part of the one people that is being asserted as the legitimate expression of membership in the community of the state. In addition, in-migrants to the state have been regularly asked to surrender previous cultural identities and submit to the dominant one of the putative nation-state. 


\section{JOURNAL OF WORLD-SYSTEMS RESEARCH}

Once again, however, this is essentially a political question. And in the past half-century, there have been important movements of resistance to this process. The resistance first of all has been the work of groups that consider themselves somehow more indigenous to the region than others - for example, within the settler states. Or they have been the resistance of groups who have been conquered by more powerful neighbors and are seeking to "revive" their language or their autonomous institutions. Today centrifugal forces are coming to be at least the equal of centripetal forces within the political-cultural lives of the world's states. The virtues of being a pluri-national state or a multi-cultural state are now being proclaimed in some countries.

The hard, cold fact is that there is no real possibility of creating truly multi-national states with different policies in different zones concerning land rights, except possibly when the socalled Indigenous populations are an absolute majority of the population, as in Bolivia. The clearest instance of this impossibility is occurring right now in Ecuador.

Ecuador is considered by world standards a state governed by left forces, one of the most radical politically in Latin America. The current president, Rafael Correa, was elected with the strong support of the federation of Indigenous movements in Ecuador, CONAIE. He is today in deep conflict with CONAIE. What happened?

The policies that give Correa the image of a political radical in today's world is first of all that he takes much geopolitical distance from the United States, and secondly his stance in regard to the foreign mining companies that have held various kinds of concessions in mineral-rich Ecuador. He moved to revoke many of these concessions in order to force the mining companies to renegotiate the terms of their arrangements. He did this in order to obtain far greater revenues for the Ecuadorian government in order to "develop" in various ways the country. Such attempts to reduce the advantages of foreign corporations in favor of higher revenues for the states in which these corporations operate have been a standard element in world politics for at least half a century and have been generally considered to be a mark of a left position in world politics.

CONAIE is not opposed to reducing the power and advantages of foreign mining corporations. But they represent those parts of the population who are still largely living on land that is not titled. The groups they represent also are disproportionately located in the regions in which mining has been or will be undertaken. They therefore are the most immediately subject to the negative ecological consequences of such operations as well as to the land displacement consequences that have occurred or may occur in the future.

The position of CONAIE is that Ecuador should change its constitution to proclaim itself a plurinational state. Furthermore, they demand the right of the Indigenous communities to give prior consent before extractive projects occur in their region. In part, they intend to deny such rights, although it is possible they will also in part simply demand control over the income that may come from consent, control that would otherwise fall to the Ecuadorian state.

Correa and CONAIE have also come into conflict over water. In this matter too, the government wished to control access to water resources, including the possibility of privatizing it. CONAIE insisted on absolute public and community control over water resources.

Finally, there was a dispute over the prospection for oil in a national park area called Yasuni. Correa took the position that the government might renounce such prospection if countries in the global North compensated it for the loss of revenue, a proposal that did not go 


\section{JOURNAL OF WORLD-SYSTEMS RESEARCH}

very far. He has reserved the right to proceed with prospection, with the strong support of the national oil corporation, Petroecuador.

This account of recent events in Ecuador illustrates the fundamental dilemma of the world left. On the one hand, the world left, especially in the global South, has stood for measures that would reduce the enormous real gap with the global North. Correa is simply pursuing this objective. On the other hand, the world left (or at least a growing portion of it) is standing against further commodification of land rights and further ecological degradation of the world. CONAIE is simply pursuing this objective.

The two strategies are contradictory and incompatible one with the other. Land rights stand as the crucial deciding point. It is not at all clear today which way the world left, as social movement, intends to go. At the moment, collectively it seems to be trying to go in both directions at the same time. This is difficult, indeed probably impossible. The conflicts within the world left about their fundamental strategy of global change risks canceling all possibility of a successful outcome in the continuing struggle over the successor system to a capitalist worldeconomy that is in structural crisis. 